This revised version was accepted on and is now published as:

Vandekerckhove W., Emmanuel M. (2019) A Rancièrian Method of Exploring Notions of Management and Organization Through the Artistic Gaze. In: Neesham C., Segal S. (eds) Handbook of Philosophy of Management. Handbooks in Philosophy. Springer, Cham. DOI 10.1007/978-3-319-48352-8_30-1

\title{
A Rancièrian Method of Exploring Notions of Management and Organization through the Artistic Gaze
}

\author{
Wim Vandekerckhove, University of Greenwich, London, United Kingdom \\ w.vandekerckhove@greenwich.ac.uk \\ Myrtle Emmanuel, University of Greenwich, London, United Kingdom \\ m.emmanuel@greenwich.ac.uk
}

\begin{abstract}
This chapter suggests that Jacques Rancière's aesthetics of politics can be applied as a method for questioning our understanding of management. We explain the method through demonstration. More precisely, we contrast organization shown in the work of the video artist Francis Alÿs with Gareth Morgan's seminal palette of images of organization. We argue that Morgan's metaphors convey a distribution of sensitivities and sensibilities with regard to organization that partition and tie people to particular places and functions in organizations. The work of Alÿs involves a dissensus of that partitioning and hence a rupture of business ethics based on images of self-serving organizations. We assert that this dissensus opens the possibility for a business ethics scholarship that decenters the organization and fundamentally changes how we can ethically speak of organizations, i.e. how we can $d o$ business ethics.
\end{abstract}

\section{Keywords}

aesthetics of politics, metaphor, Morgan, organizational aesthetics, Rancière, Alÿs

\section{Introduction}

The field of organizational aesthetics is a young one (Bereson \& de Monthoux, 2017), and is currently comprised of two streams, of which the key authors are Antonio Strati and Pierre Guillet de Monthoux. 
Antonio Strati's stream 'emphasises aesthetics as a central but forgotten dimension of 'organizational life' [and] focuses on sensible knowledge and aesthetics judgment in everyday organizational practices' (de Monthoux and Strati, 2008: 4). Pierre de Monthoux's stream sees 'the arts as an arena and laboratory for aesthetic experiments', and thus studies the arts as 'showcases of aesthetic practices threatened and marginalised by bureaucracy and corporate managerialism' (de Monthoux and Strati, 2008: 4).

Whilst de Monthoux and Strati insist their approaches are complementary, scholars working in Strati's stream seem to have little interest in artistic work, or work from the axiom that everyone is an artist. In contrast, scholars working from de Monthoux's Art firm approach primarily have an interest in how the artistic is managed, or how management approaches threaten the artistic. Beyes (2008) suggested what can be regarded as a third approach in his paper on Rancièrian aesthetics. For Rancière (2010), art is a 'dwelling in a common world' - a way-of-being. It is however a rupture-ous dwelling. Art reconfigures the sensible; it is a 'dissensual re-configuration of the sensible' (Rancière, 2010: 140). He defines 'politics' as another form of such dissensus, thereby distinguishing politics from police. The latter denotes 'a symbolic constitution of the social' (Rancière, 2010: 36), a partition of the sensible as a dividing-up of the work and of the people. This partition separates and excludes, as well as allows participation:

Society here is made up of groups tied to specific modes of doing, to places in which these occupations are exercised, and to modes of being corresponding to these occupations and these places (Rancière, 2010: 36).

Politics then, is a rupture of that partitioning. In this sense Rancière writes of the 'aesthetics of politics', precisely because art also ruptures established partitions of the sensible. However, art is not educational; art cannot, through the artist's intention, educate the spectator into political subjectivation. Art 'may create a new scenery of the visible and a new dramaturgy of the intelligible' (Rancière, 2010: 19) but it 'cannot know or anticipate the effect that its strategies of subversion may or may not have on the forms of the political subjectivation' (Rancière, 2010: 19). Hence, we can look at art to find alternative arrangements of the sensible, of what can be shown and said, of (un)tying groups to functions and places. Because management and organization revolve around division of labour and resources - partitioning groups, functions, and places - , in this article we turn to works of art to find ruptures of such partitioning, and thus turn to art as an aide to the philosophical questioning of organization.

More precisely, we use the work of a contemporary video artist, which shows visualizations of organization as a coordinated division of labour: When Faith Moves Mountains by Francis Alÿs (2002). This is not deliberate work about organization. Rather, a coordinated division of labour is made visible as part of another intervention by the artist. Hence, organization is a secondary yet undeniable layer in the work. The primary layer of this particular work is found in the artist's oeuvre, the artistic gaze that shapes a body of work. We take this secondary approach for two reasons. The first is that, if artwork is indeed about organization or management itself, merely describing the work would make little contribution to the work 
itself, apart from promoting it. This chapter is different and does make a contribution, by focusing on something that is figured in the artwork but haphazardly found its way into the work, as part of a broader rearrangement of the sensible. In this way we might say that we are reading between the artist's lines.

The second reason is related to that and revolves around Rancière's dislike for critical art. Critical art mistakenly assumes a direct cause-effect relation between the educational intention of the artist, the educational content of the artwork, the spectator's reading of the work, and political subjectivation. Because such direct relation does not exist, 'art with a message' ends in disappointment (Charnley, 2011). As mentioned earlier, Rancière posits that such subjectivation may or may not happen, and in any case is not predictable; it may happen in a very different way from what the artist intended (Wildemeersch, 2019). This is echoed in Bishop's (2006) attack on a tendency to evaluate art in ethical rather than aesthetic terms. We should be careful not to reduce artistic expressions of concerns about pleasure, visibility, engagement, and conventions of social interaction to moral criteria (Charnley, 2011). Hence, our Rancièrian approach is not to read a message into these works of art, let alone the artist's message about organization. Rather, it is to start from the dissensus found in the artist's oeuvre, to arrive at a questioning of our partitioning involved in organization. Writing in a similar approach as this article, Wildemeersch (2019) states that '[dissensus] relates to an interruption in the taken-for-granted (or natural) perception of reality' and denotes a conflict between the senses and sense; between what we see and how we make sense of it. Thus, the approach taken in this paper is to analyze what the artist's gaze is, and from their particular arrangement of the sensible explore the implicated sensitivities (senses) and meanings (sense) with regard to organization.

\section{The Artist's Gaze: Francis Alÿs}

The work of Alÿs is often characterized as relational art (Bishop, 2006). His interventions in polemic situations are always subtle. In Watercolor, he fills a bucket with water from the Red Sea (Jordan) and pours it into the Black Sea (Turkey), thereby re-arranging connections between senses and sense with regard to colonial attitudes towards the region (Amado, 2012). In The Green Line, Alÿs walks around in Jerusalem with paint dripping from a bag, leaving a trail. His trail is like the line on a map dividing Jerusalem. Walking, and marking space by walking, is a recurring theme in the work of Alÿs. The walking leaves a residue. Thus, the walking has effects beyond the activity of walking itself, but these effects are minimal. What Alÿs shows us is a dissensus between an act and its effect. That is, we take for granted that action results in something. Yet in the work of Alÿs there is minimum result; whilst the act takes effort, the act is always futile. In Paradox of Praxis I, we see Alÿs pushing a block of ice in front of him. The ice melts, making the block smaller at every step until nothing but a wet stain remains on the street, which eventually dries up too. 
Couchez (2012) has written that what is visible in the work of Alÿs is how geography influences human emotions. What Alÿs does is to liberate bodily movement from purpose and destination. The walking is not walking towards somewhere. The gaze of Alÿs is to search for the tension between the act and the ineffective: 'sometimes doing something leads to nothing' (Alÿs, cited in Couchez, 2012: 109).

In When Faith Moves Mountains, Alÿs shows 500 volunteers moving a sand dune outside Lima (Peru), in white t-shirts and with shovels. It is not hierarchy we see here but aspects of organization that are just as unsophisticated: people in a uniform (white t-shirt), receiving instructions, working in the heat, shoveling sand in front of them, and moving in line with the other volunteers over a tall sand dune. At 7'09" we see tshirts and shovels being handed out to the 500 volunteers, and instructions are given for moving in a line (7'43"). Then, a siren goes to signal volunteers to get ready ( $\left.8^{\prime 2} 25^{\prime \prime}\right)$, and the instruction to start is given through a loudspeaker (8'36"). At 9'17" we see the line of workers going uphill, and at 9'53" a helicopter passes over to keep oversight and blows a wall of sand onto the volunteers. Although the work itself was simple and did not require skill, it did require determination to finish the work in challenging conditions. Participants reported: 'When you sign up for something you have to finish it' (8'14') and 'It was torture because of the sun, the heat ...' (8'17').

As in the other work of Alÿs, futility mocks function, purpose, and efficiency, but it is not meaningless. Moving a mountain is the summum of the impossible and pointless task. And yet people do it. The absurdness of the task was immediately clear to participants: 'the idea of moving a sand dune [...] this crazy idea' (2'01'), 'These guys coming down here to waste their time' (2'11'). A number of times throughout the video the impossible task for an individual is juxtaposed with the same task being simple when approached with a large number of people, i.e. through organization. This notion of collectivity is apparent at the formation stage, e.g. 'At first I thought it was ... just silly. To move a stone, to move a rock ... but I got more involved because it's about doing something with a bunch of people, no?' (3'22'), 'We all agreed: "Let's go". Everyone with his own reasons' (3'34"), and 'The main persuasion was from one friend to another' (3'39"). But not only does the video show organization based on a community, it also shows how the work performed collectively on an absurd task is building community.

When we arrived, we were in the middle of this shanty town. I thought it was strange, but ok. Then we climbed the dune and reached the other side. I mean, when we got to the top and started to go down, I paid more attention to the houses, to the people living there. I felt ... not sorry but it made me think (4'14"-4'34").

The shoveling up and down the sand dune is marking space. The mark itself is minimal - each movement of the shovel lifts a bit of sand and puts it $10 \mathrm{~cm}$ further, and the movement of the dune cannot be noticed. But the space that is marked is one of a community: 'Up at the top, we could see for miles around' (11'05'), 'We felt on top of the world, you know' (11'09'). When they reach the end point at the other side of the dune, 
shouts of joy, achievement and celebration are heard. It is almost like the end point marks the establishing of the community of those who moved a mountain:

'Everyone was waiting for that moment! Like: We're getting there, we're nearly there ...' (12'32”) "And when we started to get to the very last part, when they said "Continue shoveling to the end", everyone began shoveling harder and when we were about to finish everybody started screaming' $(12$ '41”)

'The truth is that the people who took part felt totally involved. And the fact that it took on such a huge dimension means that it will generate one story after another. And the story will be passed on like an oral tradition' (13'26”)

People in this area were unemployed and in need of an economic project that would make them productive. Yet the organization Alÿs shows is highly unproductive. Alÿs said that the guiding idea for this work was 'maximum effort, minimum result' (Alÿs, 2002). Indeed, the movement of the dune was infinitesimal. The day after the event, one cannot notice the difference. Hence the event is a non-event. Yet people will recount this story. In this sense, Alÿs introduces a rumour in the narratives of Peru (Biesenbach \& Starke, 2010): the day people moved a mountain. The organization Alÿs sets up is an intervention in the group relations of people; it creates an oral tradition that might be constitutive of a community, as creating a space of belonging.

\section{Dissensus of Sensibility}

We noted in the introduction that we would use dissensus visible in works of art as an aide to the philosophical questioning of management and organization. Our claim is that the work of Alÿs ruptures the partitioning of sensitivities (and hence also of sense) of organizations. Nevertheless, Alÿs shows us 'organization'. So, to what extent is this a rupture? In other words, what exactly are we taking for granted in Rancière's words, 'policed' - when we imagine 'organization', and how is what Alÿs shows us a dissensus of that?

To answer this question, we explore the assumptions inherent in the mainstream images of organization, as written up by Morgan (1986). The authoritative work of Morgan has continued to dominate our understanding of metaphors and their implications for organizational behaviour and management (see Morgan, 1980, 1983, 1986, 1997, 2006, 2011, 2016). Scholars have since extended this work to include the 'Learning Organization' metaphor denoting organizational, team and individual double and triple loop learning (Senge, 1990); the 'Icehotel' metaphor that is cognisant of a temporary, emergent organizational design capturing unifinality, purity, eco-coreness and rebirth (Pinto, 2016) and the 'Justice metaphor' as a framework for exploring and resolving gender and inequality (Kemp, 2016). 
In his seminal work on 'Images of Organization', Morgan (1986) identified eight different metaphorical ways of construing organizations. These include organizations as machines, as organisms, as brains, as cultures, as political systems, as psychic prisons, as flux and as instruments of domination. Metaphors are defined as images, words or literary devices for embellishment and evoke meaning (Morgan, 1980; 2011; Oswick et al, 2002) or as a figurative speech taking the source domain and overlapping it with the target domain for rhetorical effect (Pinto, 2016: 892). Despite Morgan's belief that metaphors are ways of seeing and thinking about organizational life, there are reservations against the overly-focused use of metaphors as rarefied and abstracted epistemological or metonymy constructs (see Morgan's commentary, 2016). The analytical focus of the eight metaphors is also laden with functionalist and normative connotations that are 'cognitively prescriptive rather than liberating' (Oswick et al, 2002: 298).

Consequently, the 'one best way' of thinking and viewing organizational experience is more likely to constrain generative knowledge. Likewise, Morgan acknowledges this problematic nature of metaphors in postulating:

I feel that one of the big problems in this field rests in the fact that people often assert their own personal perspective on metaphor as "the view" or the "best view" when in point of fact it is just "a view" that happens to make sense from their perspective. It is a simple trap to fall into, and I willingly recognize that some of my own writings, especially the early ones, share this problem (Morgan, 1997: 227).

Morgan contends that social scientists, particularly in the areas of organization and management, are often trapped by their own theories and perspectives and:

as a result, they construct, understand, and interpret the social world in partial ways, creating interesting sets of insights but obliterating others as ways of seeing become ways of not seeing (Morgan, 1997:277).

Morgan's metaphors provide a multi-dimensional view of organizational science along with a framework for organizational analysis and theory construction (Örtenblad et al, 2016). Table 1 gives an overview of Morgan's eight metaphors, along with the criteria for success stemming from these metaphors.

\section{---- INSERT TABLE 1 HERE -----}

What table 1 shows is that, apart from the psychic prison and the domination metaphors, all of Morgan's metaphors depict organizational success in reference to the organization. Efficiency of the machine is the success of the machine, survival the success of the organism, learning that of brains, organizational identity that of organizational culture, power of a political system that of political systems, and self-renewal that of flux and transformation. Hence, Morgan shows us images of organization in which organizations are selfserving. The psychic prison metaphor shows organizations as traps, as structurally determined by repressed 
drives. In turn, the domination metaphor shows organization as a means to reproduce social segregation and inequality.

Thus, Morgan's palette of how we can see and make sense of organizations has but three colours: 1) selfserving, 2) reproducing human deficiency, and 3) reproducing societal deficiency. None of these, let alone any mix of these ground colours, seem apt to induce ethical 'ways of thinking' or 'ways of being' (Morgan, 2016). All of the three major ethical schools encompass a notion of otherness that constitutes the ethical: in deontology this is the intrinsic value of any human being or the Kantian humanity-as-an-end-in-itself, in consequentialism it is the effect of the action at hand on the wellbeing of others, and in virtue ethics it is the other's perception and recognition of my behaviour. It follows that the ethicality of organizations must involve an understanding of organizations that includes an exteriority to organizations, i.e. the ethicality of organizations has its reference outside of the organization. Morgan's metaphors do not meet that criteria. He writes that we need to

think about all metaphors in terms of their generative potential and judge the power of a particular metaphor in these terms [...] The focus on generative potential also leads to a focus on the question 'generative for what and for whom?' (Morgan, 2016: 1035-1036)

What Morgan asserts here - namely, that images or metaphors bridge ways of thinking and ways of being, and in this sense have generative potential - resonates with what Rancière writes about the distribution of the sensible (Rancière, 2010: 44, thesis 7). The possible forms of partaking in work are defined by the 'modes of perception in which they are inscribed'. Hence, the relation between what we share (organization) and the specific role or part we can take in that is determined by our sensory experience. That is why the image is so important. The image itself is a 'distribution of what is visible and what not, of what can be heard and what cannot (ibid.). Different metaphors render different images that define different possibilities of partaking namely, Morgan's generative potential. However, Rancière distinguishes two ways of performing such a distribution of the sensible: police, and politics. The police principle denotes an absence of void in the distribution of the sensible. There is no Other in Rancière's police as a symbolic constitution of the social. Everyone is tied to a specific function, to a place to exercise that function, and to a mode of being that corresponds with that function and place. There is no space for what 'is not'. In contrast to this 'policing', Rancière's politics 'is an intervention in the visible and the sayable' (Rancière, 2010: 45). This intervention consists of showing the void within the police partitioning. Rancière conceptualizes politics as a dissensus, as a showing of two worlds in one. It is the 'demonstration of the gap in the sensible' (p. 46) rather than a confrontation between interests or stakeholders.

Morgan's images do not show this gap. They are either closed (self-serving) or merely reproduce(d). Kemp (2016) asserts that women's equality and inequality cannot be seen in scholarly work using Morgan's images. That is because these images do not make women's equality and inequality visible. What cannot be seen cannot be thought and therefore cannot become. Hence why Kemp (2016) had to construct new images 
to release our trapped ways of seeing and thinking organizations, and also make organizational praxis for women's equality possible. Indeed, one cannot simply add to an image what that image does not show. In Rancière's words, 'otherness does not come to politics from the outside' (Rancière, 2010: 61). Hence, since we asserted that the ethicality of organizations lies outside of the organization, it follows that the image of organization that allows us to think and enact the ethical must be an image that already holds its otherness.

We will argue that Alÿs shows us such an image but before we do that, we want to make clear that our argument is not simply that Morgan's images are inapt for business ethics, but also that much of the business ethics scholarship does not have the images to think ethics. Morgan writes that he chose his metaphors so that his book 'would illustrate a broad range of social theory' (Morgan, 2016: 1039), more precisely different strands of organizational theory. We noted earlier that Morgan's book had (and has) a profound influence on organizational scholars, as sales figures and citation metrics can evidence. Thus, since Morgan's metaphors are the images of mainstream organizational theory schools, we may assume that business ethics scholarship will also have been influenced, if not by Morgan's images directly, then by these mainstream schools in organizational theory. We would thus expect business ethics scholarship to suffer from distributions of the sensible that leave no place for the void, or that do not hold otherness.

As of yet, very few scholars have explicitly discussed notions of ethics and morality in the context of metaphors. An exception is Alexander (2005) who writes that metaphorically morality is health and that hence, business ethics is about the health of an organization. Rhodes and Pullen (2018) reviewed the critical business ethics literature, i.e. critiques of business ethics scholarship from an ethical lens, and

identified three lines of critique supporting the idea that corporate self-interest can be enhanced using ethics: (1) that ethical programmes are only engaged in when there is a demonstrable 'business case' to do so, (2) that ethics is used as a form of 'impression management' designed to create a favourable and beneficial organizational image and identity among stakeholders, and (3) that organizations seek to position themselves as ethically self-regulating so as to ward off demands for external regulation, and hence to increase their independent power. (p. 486)

Rhodes and Pullen further assert that business ethics scholarship does not explore the possibility of noninstrumentally rational means-end accounts of business self-interest. They then go on to offer such an account through Agamben's political theology. Thus, corporate business ethics are practices of glorification of corporate power. This glorification can be seen in the 'repeated acclamation of the righteousness of power' (Rhodes \& Pullen, 2018: 492) whereby power is rendered 'unaccountably powerful' (ibid). What needs to be made unthinkable is that 'the empty centre of the corporation be revealed as meaningless' (ibid). What we assert in this article is that Morgan's images of organization contribute to hegemony work that makes possible corporate business ethics as a glorification of corporate self-interest. In Rancière's words, these images are policing; there is a consensus of what can be shown and what can be said (senses and sense), and this consensus confirms the allocation of people to places and functions, of which the reference point is the self-interest of the organization. In contrast, Rancière's politics occurs when there is a dissensus 
between senses and sense. For Rancière (2009: 5) it is possible that 'the artistic experience - as a refiguration of the forms of visibility and intelligibility of artistic practice and reception - intervenes in the distribution of the sensible'. Such a 'refiguration' is not the same as choosing the side of the underdog or seeing a victim for whom we would fight. That would still amount to confirming the given partitioning or distribution of sensitivities and understanding.

Let us turn to an example that Rancière gives himself. In a text from 2009, Rancière mentions a passage in a revolutionary workers' newspaper published in 1848, in which a joiner (woodworker) describes a day at work. This piece is presented as a kind of diary:

Believing himself at home, he loves the arrangement of the room so long as he has not finished laying the floor. If the window opens out onto a garden or commands a view of a picturesque horizon, he stops his arms a moment and glides in imagination towards the spacious view to enjoy it better than the possessors of the neighbouring residences. (Rancière, 2009: 7)

Rancière writes that the joiner here puts two worlds in one, by speaking of belief and imagination and opposing their enjoyment to the reality of possessions, or to a 'disconnection between the activity of the hands and that of the gaze' (p. 7). What the joiner's writing does is to dismantle a body of experience that was partitioned to a specific place-occupation, i.e. 'the artisan who knows that work does not wait and whose senses are geared to this lack of time' (p. 8). The aesthetic judgement is possible only by 'ignoring to whom the palace belongs, the vanity of the nobles, and the sweat of the people incorporated in the palace'. However, 'this ignorance is by no means the illusion that conceals the reality of possession' (ibid). Rather, it is the means for building a new sensible world. Rancière asserts that 'this aesthetic description is in its proper place in a revolutionary newspaper because this dismantling of the worker's body of experience is the condition for a worker's political voice' (ibid). This passage illustrates well how dissensus is not the same as conflict. Dissensus adds a supplement which cannot be described as a part of the parts. In that sense it is twoworlds-in-one.

There is a similar dissensus at work in the video of Alÿs. Table 2 provides a list of senses and sense that can be identified in the video.

\section{----- INSERT TABLE 2 HERE -----}

In this video, the heat the people work in, the dust and sand blown into them by the helicopter, and the uniform instructions contrast with the pace of walking, the chatter, and the openness of the surroundings. At the same time, the futility of the performance and the absurdness of moving a dune contrast with the sense of community people report and the amazing story they believe they are making. The video does not deny the heat, the instructions, the absurdness or futility. It shows all of these. But it also shows how the marking of space is creating community. Not in defence or justification of the organization; rather, by ignoring the heat, the absurdness, etc. Alÿs shows us an image of organization that has the void/otherness already in it. 
Rancière would say that the aesthetic judgement here is disinterested: whilst the video is not 'about' an organization, it does not deny or conceal the organization. Another, sensible, world speaks from the video, suggesting a refiguration of people and organizations. It seems to us that this refiguration questions a number of assumptions about how people are tied to the space of organization. The particular assumptions that are ruptured in the work of Alÿs are:

1) organizations are (not) spaces for self-development: the video does document self-development of people, but this development is not in shoveling sand to move a dune. Rather, the self-development happens where the organization is ignored. In that sense, the space for self-development transcends the organization.

2) organizations are (not) spaces of productivity and efficiency: moving the dune is futile and the way it is organized is highly inefficient. Yet community is built; a story has been produced. However, what is produced is not an organizational goal. In that sense, it is the people, not the organization, that is the space of productivity.

3) organizations are (not) spaces of community: as in the other work of Alÿs, marking space is the activity that holds meaning beyond the activity itself. In this video, moving a dune is the activity but this marking of space leads to meaning beyond the dune, for example when people get on top of the dune ('on top of the world'), or the story for generations to come. Hence, it is not the organization that is the space of a community, but a community may well hold or exploit a number of organizations within its space.

4) organizations (do not) have memories: the organization ceases to exist. Yet this event is memorable. Thus, it is not the organization that has a memory (cf. Morgan's brain metaphor). Rather, people have memories of organization. It is perhaps in this way that the organization is most important, i.e. in the memory of people.

This refiguration of people and organization decenters the organization from our understanding of organization. Even if our memory of an organization figures in a story through which we give our life meaning, it is our memory of what we did rather than the fact that the memory belongs to the organization. We do not need to deny or conceal the realities of work in organization in order to imagine organizations as meaningless or disposable. In building our communities and marking our spaces, the attributes of organization are not really what matters. We submit here that this suggests another business ethics is possible, breaking the hegemony of business ethics that unquestioningly assumes self-serving organizations.

\section{Concluding Remarks}

In this chapter we argued that the organization shown in Francis Alÿs's video When Faith Moves Mountains (2002) is a dissensus of common notions of organization as they can be found in Morgan's methaphors. We used a Rancièrian lens to discuss the implications of this for business ethics scholarship. We argued that the organization shown in Francis Alÿs's video When Faith Moves Mountains (2002) is a dissensus of common notions of organization found in academic literature. 
Rancière's aesthetics of politics implies that ruptures of the established ways of what can be said and shown can be found in art. Alÿs's art video shows people being organized to move a sand dune in challenging conditions. Much could be said about this 'organizing' from a business ethics perspective - pointless work, low-skilled tasks, workers' treatment, etc. Yet how workers make sense of it, and how Alÿs allows us to make sense of it through what he shows, fundamentally changes the perspective of how we can ethically speak of organizations, i.e. how we can do business ethics. Rather than being about how people are organized, this Rancièrian repartitioning of senses and sense turns business ethics into speaking about what people (can) do with organizations. It alters the unit of analysis from the organization to the life of humans and communities. As such, it demands from us to turn away from making the business case for ethics or constructing the strategic importance of CSR.

A confrontation with Gareth Morgan's (1986) seminal palette of images of organization allows suggestion of how radical Alÿs's repartitioning is. We argue that even Morgan could not imagine organizations as disposable consumables, while this is precisely what Alÿs is showing us. Morgan (2006) advocates the use of metaphors for making sense of organizational experience. Morgan $(1986,2006)$ argues that metaphors are useful ways of viewing and thinking about the world and about one aspect of phenomena in terms of another. This therefore provides a basis for both hermeneutical and heuristic value representing a departure from the objectivist to the subjectivist view of sense-making whereby the elucidation of a particular phenomenon lies with the 'knower' rather than the 'known' (Morgan, 1997).

In this chapter, we have used a Rancièrian lens to question the possibility of business ethics when understanding organizations from any of Morgan's eight metaphors. Such questioning is triggered by an alternative visualization of organization, which we have found in the work of Alÿs. We have argued that Morgan's metaphors are ethically constrained by a hegemonic self-referential understanding of business ethics, and that a Rancièrian dissensus visible in the work of Alÿs offers a possibility for heterogeneity in business ethics.

Our assertion is that business ethics scholarship, because it is constrained by a hegemonic partitioning of senses and sense, is caught up in a self-referential understanding of organization. Alÿs's video offers a repartitioning of people, work and organization. This visual and cognitive decentering of organization allows for a heterogenous business ethics, one that speaks of people using organizations in and for their lives, and hence a business ethics that does not have the organization as its reference point. Rather, we - people in communities - are the reference point of a business ethics that is not 'ethics of business' but rather 'ethics in business'.

\section{Cross-References}


Aethetics, Management, and the Organization of Space \{ HYPERLINK

https://link.springer.com/referenceworkentry/10.1007/978-3-319-48352-8_20-1 \} 


\section{References}

Alexander JK (2005) Metaphors, Moral Imagination and the Healthy Business Organisation: A Manager's Perspective. Philos of Manag 5(3): 43-53

Alÿs F (2002) When Faith Moves Mountains. Available via http://francisalys.com/when-faith-movesmountains/. Accessed 6 February 2017

Amado M (2012) Contested territories: Dissensus and the city. Dorsky Gallery, New York

Bereson R, de Monthoux PG (2017) Poetic pragmatism and artful management. Philosophy of Management 16(3): 191-196

Beyes T (2008) Reframing the possible: Rancièrian aesthetics and the study of organization. Aesthesis 2(1): $8-41$

Biesenbach K, Starke C (2010) Francis Alÿs: A to Z. In: Godfrey M, Biesenbach K (eds) Francis Alÿs: A story of deception. Tate Publishing, London, pp 34-43

Bishop C (2006) The social turn: Collaboration and its discontents. Artforum, February 2006.

Charnley K (2011) Dissensus and the politics of collaborative practice. Art \& the Public Sphere 1(1): 37-53

Couchez E (2012) A line going out for a walk. On the rhetoric of walking in Francis Alÿs's oeuvre. Image \& Narrative 13(3): 101-114

de Montoux PG, Strati A (2008) Ponte dei Sospiri: Bridging art and aesthetics in organisational memories. Aesthesis 2(1): 4-7

Kemp LJ (2016) Trapped by metaphors for organizations: Thinking and seeing women's equality and inequality. Human Relations 69(4): 975-1000

Morgan G (1980) Paradigms, Metaphors, and Puzzle Solving in Organization Theory. Administrative Science Quarterly 25(4): 605-622

Morgan G (1983) More on metaphor: Why we cannot control tropes in administrative science.

Administrative Science Quarterly 28(4): 601-607

Morgan G (1986) Images of Organization. Sage, London

Morgan G (1997) lmaginization: New mindsets for seeing, organising, and managing. Sage, London

Morgan G (2006) Images of organization, 3rd ed. Sage, London

Morgan G (2011) Reflections on Images of Organization and Its Implications for Organization and Environment. Organization \& Environment 24(4): 459-478

Morgan G (2016) Commentary: Beyond Morgan's eight metaphors. Human Relations 69(4): 1029-1042

Örtenblad A, Putnam LL, Trehan K (2016) Beyond Morgan's eight metaphors: Adding to and developing organization theory. Human Relations 69(4): 875-889

Oswick C, Keenoy T, Grant D (2002) Metaphor and Analogical Reasoning in Organization Theory: Beyond Orthodoxy. Academy of Management Review 27(2): 294-303

Pinto J (2016) 'Wow! That's so cool!': The Icehotel as organizational trope. Human Relations 69(4): 891914

Rancière J (2009) The aesthetic dimension: Aesthetics, politics, knowledge. Critical Inquiry 36: 1-19 
Rancière J (2010) Dissensus: On politics and aesthetics. Continuum, London

Rhodes C, Pullen A (2018) Critical business ethics: From corporate self-interest to the glorification of the sovereign pater. International Journal of Management Reviews 20: 483-499

Senge PM (1990) The fifth discipline: the art and practice of the learning organization. Doubleday/Currency, New York

Wildemeersch D (2019) What Can We Learn from Art Practices? Exploring New Perspectives on Critical

Engagement with Plurality and Difference in Community Art Education. International Journal of Art \&

Design Education 38(1): 168-181 
Table 1. Morgan's metaphors, key aspects, and criteria for success

\begin{tabular}{l|l}
\hline Organizations as ... & Criteria for success \\
\hline Machines & Efficiency \\
\hline Organisms & Survival \\
\hline Brains & Learning \\
\hline Cultures & Identity \\
\hline Political systems & Power \\
\hline Psychic prisons & Determinism \\
\hline Flux \& transformation & Self-renewal \\
\hline Instruments of domination & Social reproduction
\end{tabular}


Table 2. Senses and sense in When Faith Moves Mountains (Alÿs, 2002)

\begin{tabular}{l|l} 
Dissensus & notions (visible or expressed) \\
\hline Senses & $\begin{array}{l}\text { heat } \\
\text { dust } \\
\text { lined and forwards } \\
\text { siren } \\
\text { walking } \\
\text { openness } \\
\text { chatter }\end{array}$ \\
\hline Sense & $\begin{array}{l}\text { marking space } \\
\text { community } \\
\text { story } \\
\text { futility of organizational performance } \\
\text { absurd organizational purpose }\end{array}$ \\
\hline
\end{tabular}

